\title{
ANALISA PERBANDINGAN OBAT ANTIHIPERTENSI (OHT) DENGAN KEJADIAN POLA TEKANAN DARAH NONDIPPERS PADA PENDERITA HIPERTENSI TANPA STROK ISKEMIK
}

\author{
Mochammad Erwin Rachman ${ }^{*}$, Cahyono Kaelan ${ }^{*}$ ) \\ ${ }^{*}$ Staff Dosen Fisiologi Fakultas Kedokteran UMI Makassar \\ ${ }^{* *}$ Staff Dosen Patologi - Neurologi Fakultas Kedokteran UNHAS \\ Email : $\underline{\text { m.erwinrachman@yahoo.com }}$
}

\begin{abstract}
The pattern of blood pressure hypertensive nondippers is one of the factors that increase the risk of suffering from cardiovascular and cerebrovascular disorders , but the effect of antihypertensive drugs work period (OHT) relating to the type of the pattern of blood pressure in patients with hypertension hypertensive nondippers still not widely studied. This study aims to analyze the working relationship with the incidence pattern of antihypertensive drug blood pressure hypertension nondippers in patients with post- acute stroke ischemic stroke with and without hypertension. The method used was a cross -sectional study with 60 samples ( 30 hypertensive patients with ischemic stroke and 30 patients with hypertension as a control) of the Hospital Dr. WahidinSudirohusodo Makassar and its network in 2013 . The results showed chi-square test patterns obtained blood pressure in hypertensive nondippers larger user group types ACEI captopril group OAH 18 (94.7\%) with grades ( $p>$ 0.05 ) with $O R=4.6$. It can be concluded that there are patterns of blood pressure hypertension incidence nondippers against ischemic stroke incidence was greater in OHT group ACEI types captopril group, although not significantly.
\end{abstract}

Keywords: Dippers, Nondippers, Hypertension, Ischemic Stroke.

\section{PENDAHULUAN}

Hipertensi dapat mengakibatkan kerusakan berbagai organ target seperti otak, jantung, ginjal, aorta, pembuluh darah perifer, dan retina. Beberapa penelitian secara cross sectional membuktikan bahwa kerusakan organ target lebih erat hubungannya dengan hasil pengukuran tekanan darah selama 24 jam atau Ambulatory Blood Preasure (AMBP) daripada tekanan darah sesaat di klinik (Gumelar G.,2009). Hipertensi tetap menjadi faktor risiko yang dominan dan indikator prognosis pada pasien dengan strok.Risiko strok secara langsung berkaitan dengan peningkatan tekanan darah.Sejumlah studi klinis telah menunjukkan bahwa kontrol hipertensi menyebabkan penurunan kejadian strokdi masyarakat. Pengendalian hipertensi sangat penting untuk pencegahan stroke pada semua kelompok umur. 
Analisa perbandingan obat antihipertensi (OHT) dengan kejadian pola tekanan darah nondippers pada penderita hipertensi tanpa strok iskemik

Sebuah laporan menyebutkan peningkatan angka perdarahan intraserebral di India mungkin karena hipertensi tidak terdeteksi dan tidak terkendali (Jain S et al.,2004).

Pada orang normal, tekanan darah mengikuti pola sirkardian,yaitu tekanan darah mengalami penurunan pada malam hari dan mengalami kenaikan pada pagi hari.Demikian pula pada sebagian besar penderita hipertensi, juga mengikuti pola sirkadian orang normal (dippers).Tetapi, pada penderita hipertensi nondippers tidak terjadi penurunan tekanan darah malam hari.Kejadian penyakit kardiovaskular maupun strok lebih sering timbul pada penderita hipertensi nondippers daripada penderita hipertensi dippers.Kerusakan organ target yang lebih berat erat hubungannya dengan pasien dengan tekanan darah tetap tinggi pada malam hari (nondippers) daripada pasien yang tekanan darahnya menurun secara normal pada malam hari (dippers) (Gumelar G.,2009). Sebagai contoh, hasil penelitian dari Verdecchia dan kawankawan secara kohort prospektif terhadap1100 penderita hipertensi, dilaporkan angka kematian rata-rata pada nondippers dan reverse dippers lebih tinggi daripada dippers. Hasil penelitian Yamamoto membuktikan bahwa tekanan darah yang tinggi pada pengukuran secara ambulatory (AMBP), khususnya tekanan darah yang tinggi pada malam hari dan penurunan tekanan darah yang kurang pada malam hari, akan menyebabkan efek yang merugikan (bertambah luasnya lesi) pada lesi iskemik yang tenang (silent ischemic lesions) dan strok simptomatis pada pasien dengan infark lakuner (Gumelar G.,2009).

Tekanan darah berfluktuasi pada siang hari. Data yang berhubungan dengan hal ini sangat meningkat dalam beberapa tahun terakhir sejak monitor tekanan darah ambulatori digunakan. Suatu pola yang konsisten telah dikonfirmasi pada banyak orang yang normotensi dan hipertensi yaitu :Level tekanan darah tertinggi terjadi setelah jam 10.00 pagi dengan puncak sekitar tengah hari, namun sering menetap sampai jam 06.00 sore.Terjadi peningkatan tekanan darah dari saat atau sebelum bangun (sekitar jam 06.00 pagi), dengan tekanan darah naik hingga 20/15 $\mathrm{mmHg}$ pada kebanyakan orang.Terjadi penurunan tekanan darah antara $10-20 \%$ pada akhir malam dan saat pergi tidur, dengan titik nadir sekitar jam 03.00 dini hari (Schacter M.,2010). Rachman ME et al 
Analisa perbandingan obat antihipertensi (OHT) dengan kejadian pola tekanan darah nondippers pada penderita hipertensi tanpa strok iskemik

(2011), mendapatkan gambaran bahwa rasio pola tekanan darah hipertensi nondippers (86.7\%) lebih besar dibanding dippers (13.3\%) pada pasien strok fase akut, serta bentuk pola tekanan darah hipertensi nondippers utamanya terjadi sekitar pukul 10.30 malam.

\section{Berdasarkan keterangan-} keterangan tersebut penulis ingin meneliti sejauh mana besarnya pengaruh kerja OHT jenis Captopril terhadap kejadian tekanan darah hipertensi nondippers pada penderita strokiskemik dalam pasca akut dengan penderita hipertensi tanpa strok.

\section{METODE PENELITIAN}

\section{Desain dan Lokasi Penelitian}

Penelitian ini merupakan penelitian cross sectional, pada pasien strok iskemik disertai hipertensi tanpa menderita strok di unit rawat jalan dan rawat inap RS dr. Wahidin Sudirohusodo Makassar dan jejaringnya yang dilaksanakan mulai Juni sampai Agustus 2013.

\section{Populasi Penelitian}

Populasi penelitian adalah semua penderita strok iskemik dalam fase pasca akut dan penderita hipertensi tanpa menderita strok yang berkunjung ke unit rawat jalan dan rawat inap RS dr.Wahidin
Sudirohusodo Makassar dan jejaringnya. Sampel penelitian adalah penderita dari populasi penelitian yang memenuhi kriteria inklusi, sampel diperoleh berdasarkan consecutive sampling. Kriteria inklusi semua penderita strok iskemik dengan riwayat hipertensi yang dibuktikan dengan pemeriksaan klinis dan CT scan dalam masa pasca akut sebagai kelompok penderita dan penderita hipertensi tanpa serangan strok sebagai kelompok kontrol. Kriteria eksklusi bila pasien gaduh gelisah, aktif merokok, minum kopi, penderita strok fase akut, tidak mempunyai riwayat hipertensi. Subyek yang memenuhi kriteria inklusi dilanjutkan dengan pemeriksaan tekanan darah pada pukul 10.30 WITA dan 22.30 WITA untuk menentukan pola tekanan darah dippers atau nondippers.

\section{Analisis Data}

Data yang terkumpul selanjutnya dioleh menggunakan komputer dengan analisis univariat digunakan untuk deskriptif karakteristik data dasar berupa distribusi frekuensi. Analisis bivariat menggunakan uji chi square untuk sejauh mana besarnya rasio perbedaan tekanan darah hipertensi nondippers dan dippers pada penderita strokiskemik dalam pasca akut dengan penderita 
Analisa perbandingan obat antihipertensi (OHT) dengan kejadian pola tekanan darah nondippers pada penderita hipertensi tanpa strok iskemik

hipertensi tanpa strok, menggunakan program SPSS (Statistical Package for Social Sciences).

\section{HASIL PENELITIAN}

Data dari subyek yang berhasil dikumpulkan selama penelitian ini adalah 30 orang yang menderita hipertensi disertai strok iskemik pasca akut sebagai kelompok penderita dan 30 orang penderita hipertensi tanpa strok sebagai kelompok kontrol.

Tabel 1. Karakteristik Subyek Penelitian

\begin{tabular}{l|c|c}
\hline \multicolumn{1}{c|}{ Variabel } & $\begin{array}{c}\text { HT dengan SI } \\
(\mathrm{n}=30)\end{array}$ & $\begin{array}{c}\text { HT Tanpa SI } \\
(\mathrm{n}=30)\end{array}$ \\
\hline 1. Usia (thn) & & \\
- Mean & 60.40 & 58.07 \\
- SD & 10.70 & 10.94 \\
- Rentang & $(45-83)$ & $(31-85)$ \\
2. GCS & 14.87 & 15.00 \\
- Mean & 0.34 & 0.00 \\
- SD & $(14-15)$ & $(15-15)$ \\
- Rentang & 14.70 & $6.53^{*}$ \\
3. Onset (hari) & 9.87 & $3.14^{*}$ \\
- Mean & $8-45$ & $1^{*}-12^{*}$ \\
- SD & & \\
- Rentang & 115.93 & 124.44 \\
4. MAP pkl.10.30 (mmHg) & 15.29 & 13.76 \\
- Mean & $(90.00-150.00)$ & $(93.33-124.44)$ \\
- SD & & \\
- Rentang & 114.90 & 118.11 \\
MAP pkl.22.30 (mmHg) $\quad$ Mean & 14.07 & 14.18 \\
- SD & $(90.67-149.33)$ & $(86.67-146.67)$ \\
\hline Rentang & & \\
\hline
\end{tabular}

Ket: GCS $=$ Glasgow Coma Scale, MAP $=$ Mean Arterial Pressure. ${ }^{*}=$ tahun

Data Primer

Tabel 2. Analisa perbandingan obat antihipertensi dengan kejadian pola tekanan darah nondippers pada penderita hipertensi dengan strok iskemik dan tanpa strok iskemik.

\begin{tabular}{|c|c|c|c|c|c|}
\hline \multirow{2}{*}{ Gol. OAH } & \multicolumn{2}{|l|}{ Hipertensi } & \multirow[b]{2}{*}{$p$} & \multirow{2}{*}{ OR } & \multirow{2}{*}{$\mathrm{Cl}$} \\
\hline & Nondippers & Dippers & & & \\
\hline $\begin{array}{l}\text { Captopril } \\
\text { OAH lain }\end{array}$ & $\begin{array}{l}46(82.1 \%) \\
2(50.0 \%)\end{array}$ & $\begin{array}{l}10(17.9 \%) \\
2(50.0 \%)\end{array}$ & 0.36 & 4.60 & $0.24-86.63$ \\
\hline
\end{tabular}

Nilai $p$,secara Fisher's 
Analisa perbandingan obat antihipertensi (OHT) dengan kejadian pola tekanan darah nondippers pada penderita hipertensi tanpa strok iskemik

PEMBAHASAN

Tabel 1, memperlihatkan distribusi karakteristik subyek penelitianpenderita strok iskemik pasca akut (penderita) dengan kelompok penderita hipertensi tanpa strok iskemik (kontrol) penelitian yang dikaitkan pada pola tekanan darah diurnal berupa dippers dan nondippers. Pada kelompok penderita nampak rerata usia 60.4 tahun $(S D=10.70)$ dengan rentang usia 4583 tahun dan rerata usia kontrol 58.07 tahun $(S D=10.94)$ dengan rentang usia 31-85 tahun, nilai rerata GCS pada penderita 14.87 (SD=0.34) dengan rentang 14-15 dan rerata GCS kontrol 15 (SD=0.0) dengan rentang 15-15, rerata onset penderita 14.70 hari $(S D=9.87)$ dengan rentang 8-45 hari, dan rerata onset kontrol 6.53 tahun ( $S D=3.14)$ dengan rentang 1-12 tahun. Untuk rerata MAP pukul 10.30 wita $115.93 \quad \mathrm{mmHg} \quad((S D=15.29)$ penderita dengan rentang 90-150 $\mathrm{mmHg}$, dan kontrol reratanya 124.44 $\mathrm{mmHg}(\mathrm{SD}=13.76)$ dengan rentang 93.33-124.44 $\mathrm{mmHg}$, serta rerata MAP penderita pukul 22.30 wita yaitu $114.90 \mathrm{mmHg} \quad(\mathrm{SD}=14.07) \quad$ dengan rentang 90.67-149.33 $\mathrm{mmHg}$, dan kontrol $118.11 \mathrm{mmHg} \quad(S D=14.18)$ dengan rentang 86.67-146.67 $\mathrm{mmHg}$. Tabel 2, menunjukkan bahwa pasien hipertensi yang mengalami pola tekanan darah hipertensi nondippers yang menggunakan obat anti hipertensi golongan ACEI jenis Captopril yaitu terdapat 46 orang $(82,1 \%)$ lebih besar dibandingkan dengan yang mengalami pola tekanan dippers hanya 10 orang $(17,9 \%)$. dengan hubungan perbedaan yang tidak signifikan (uji Chi Square, $p>0.05$ ), dengan kelompok pengguna obat anti hipertensi golongan ACEI jenis Captopril mempunyai resiko sebesar 4.60 kali $(O R=4.60)$ lebih besar untuk mengalami pola nondippersdibandingkan kelompok pengguna $\mathrm{OAH}$ lain pada penderita hipertensi strok iskemik dan tanpa strok.

Penelitian ini dilakukan untuk mendapatkan wawasan sekalipun jawaban mengenai pemikiran tentang peranan $\mathrm{OAH}$ jenis Captopril yang paling sering digunakan dalam terapi hipertensi yang berkaitan dengan pola tekanan darah diurnal pada penderita hipertensi berupa pola nondippers sebagai salah satu faktor resiko pemicu terjadinya strok khususnya strok iskemik. Telah diketahui bahwa strok merupakan salah satu penyebab utama dalam hal kematian, kecacatan maupun beban ekonomi di masyarakat. Hipertensi tetap 
Analisa perbandingan obat antihipertensi (OHT) dengan kejadian pola tekanan darah nondippers pada penderita hipertensi tanpa strok iskemik

merupakan faktor risiko yang dominan dan indikator prognosis pada pasien dengan strok di semua masyarakat.

Risiko strok secara langsung berkaitan dengan peningkatan tekanan darah.Terdapat bebrapa penelitian mengenai fenomena mengenai pola tekanan darah pada penderita hipertensi untuk beresiko mengalami gangguan kardiovaskular maupun serebrovaskular,yang dikenal dengan pola nondippers. Dimana pola tekanan darah nondippers menggambarkan selisih tekanan rerata aliran darah arteri (MAP) malam hari dengan pagi hari yang tetap tinggi dengan selisih $<10 \%$.

Penelitian cross sectionalini melibatkan 60 responden yang memenuhi kriteria inklusi dengan membagi kelompok penderita hipertensi dengan strok iskemik pasca akut sebagai kelompok kasus (penderita) sebanyak 30 responden dan 30 penderita hipertensi lama tanpa menderita strok iskemik sebagai kontrol. Pengukuran tekanan darah dilakukan pada responden dengan menggunakan sphygmanometer air raksa pada pukul 10.30 pagidan 22.30 malam Wita pada hari yang sama, mengingat hasil penelitian Rachman ME et al (2011) mendapatkan bentuk pola tekanan darah nondippers utamanya terjadi sekitar pukul 10.30 malam.

Pada penelitian ini karakteristik responden kelompok penderita hipertensi disertai strok iskemik memiliki rerata usia $(60.4 \pm 10.70$ tahun) lebih tua dibandingkan rerata usia penderita hipertensi tanpa strok (58.07 \pm 10.94 tahun). Adapun rerata onset penderita hipertensi strok iskemik adalah (14.70 \pm 9.87 hari) yang menunjukkan bahwa responden tidak dalam fase akut strok iskemik dan untuk menghindari prosesproses yang terjadi dalam fase akut strok iskemik dalam pengukuan tekanan darah agar dapat diperoleh nilai sebenarnya terjadi pada kelompok strok iskemik. Adapun rerata onset responden penderita hipertensi tanpa strok sebagai kontrol adalah ( $6.53 \pm 3.14$ tahun) yang menggambarkan jika kelompok kontrol telah menderita hipertensi yang lama.

Tabel 1, rerata usia responden penderita (hipertensi disertai strok iskemik) adalah $60.4 \pm 10.70$ tahun, dan rerata usia kontrol (hipertensi tanpa strok iskemik) $\quad 58.07 \pm 10.94$ tahun. Pada tabel 2, tidak didapatkanhubungan perbedaan yang bermakna (uji Chi-Square, $p>0.05$ ) pada kelompok usia kelompok penderita dan kontrol. Namun pada 
Analisa perbandingan obat antihipertensi (OHT) dengan kejadian pola tekanan darah nondippers pada penderita hipertensi tanpa strok iskemik

kelompok penderita lebih banyak terjadi pada usia $>55$ tahun sebanyak (60.0\%) dan kelompok kontrol lebih banyak pada usia $\leq 55$ tahun sebanyak (53.3\%).Hal ini sesuai dengan penelitian Rachman ME et al (2011) bahwa penderita strok lebih banyak terjadi di usia $>55$ tahun dan hasil survei yang dilakukan oleh University Hospital Newark-New Jerseytahun 2013 bahwa resiko strok meningkat dengan pertambahan usia yakni usia $>55$ tahun. Hal ini yang berkaitan dengan resiko penderita hipertensi yang lama untuk menderita strok iskemik.

Satu hal yang menarik sebagai tambahan hasil dalam penelitian ini , yaitu peranan obat anti hipertensi golongan ACEI jenis Captopril untuk mengalami pola tekanan darah hipertensi nondippers pada penderita hipertensi tanpa strok iskemik,bahwa terdapat hubungan perbedaan yang bermakna (nilai $p$, Fisher testp<0.05).Pasien hipertensi tanpa disertai strok iskemik pada sampel kontrol mengalami pola tekanan darah hipertensi nondippers paling besar (82.1\%) yang menggunakan obat anti hipertensi golongan ACEI jenis Captopril dibandingkan dengan yang menggunakan $\mathrm{OAH}$ lain. $\mathrm{Hal}$ ini jika dilihat dari hasil penelitian (Markum
HS, 2009), yaitu pada golongan Angiotensin-2 Reseptor Blocker (AlIRB) seperti Telmisartan dan Valsartan yang mempunyai afinitas kuat terhadap AT-1 receptordapat bekerjacukup lama sehingga dianggap mempunyai sifat chronotherapeutic yang baik dibandingkan golongan ACEI yaitu Captopril yang sebagian besar dikonsumsi oleh responden hipertensi tanpa strok merupakan obat golongan ACEI yang mempunyai masa kerja singkat dan sifat chronotherapeuticyang buruk, serta nilai Through at Peak Ratio(TPR) $<50$ $\%$. Pengecualian pada penelitian Yamamoto $Y$ et al (2005) bahwa golongan ACEI jenis Perindopril efektif menurunkan pola nondippers karena memiliki efek kerja yang panjang dan TPR $>50 \%$. Jadi hal ini terjadi karena golongan ACEI jenis Captopril tidak memiliki efek obat yang panjang sehingga resiko mengalami pola tekanan darah nondippers akan terjadi, walaupun dengan menaikkan dosis obat antihipertensi yang bekerja pendek untuk mencapai $T P R>50 \%$ adalah sulit dilaksanakan karena pemberian obat harus sering, dosis obat terlalu tinggi setiap pemberiannya, dan terjadinya fluktuasi tekanan darah, kemungkinan terjadi hipotensi yang berlebihan pada malam 
Analisa perbandingan obat antihipertensi (OHT) dengan kejadian pola tekanan darah nondippers pada penderita hipertensi tanpa strok iskemik

hari. Untuk itu perlunya pada pemilihan obat anti hipertensi sebaiknya harus berdasarkan variasi harian tekanan darah (chronobiologychronotherapeutic) dan efek kerja obat yang lama (nilai TPR $>50 \%$ ), sehingga resiko mengalami pola tekanan darah nondippers menjadi rendah. (Markum HM,2009).

\section{KESIMPULAN}

Kejadian pola tekanan darah hipertensi nondippers berhubungan dengan penggunaan $\mathrm{OAH}$ golongan ACEI jenis Captopril.Kelanjutan penelitian ini sebaiknya menggunakan Ambulatory Blood Pressure (AMBP) dalam memantau perubahan pola tekanan darah selama 24 jam agar hasil dapat lebih akurat.Pada setiap penderita hipertensi dalam pemilihan obat hipertensi sebaiknya memperhatikan variasi harian tekanandarah (chronobiologychronotherapeutic) dan efek kerja obat yang lama (nilai TPR $>50 \%$ ), sehingga resiko mengalami pola tekanan darah nondippers menjadi rendah.

\section{DAFTAR PUSTAKA}

Hermida RC et., al.(2000). Blood Pressure Pattern in Normal Pregnancy, Gestational Hypertension, and Preeclampsia.Hypertension.;36: 149-158.
Jain S et.al,.(2004). Loss of circadian rhythm of blood pressure following acute stroke. India. Department of Neurology, Postgraduate Institute of Medical Education and Research, Chandigarh, India.

JNC 7 Express.(2003).The Seventh Report of the Joint National Committee onPrevention, Detection, Evaluation, and Treatment of High Blood Pressure.National High Blood Pressure Education Program.NIH Publication.

Yamamoto $Y$ et al.,(2005). Effect of the Angiotensin-Converting Enzyme Inhibitor Perindopril on 24-Hour Blood Pressure in Patients with Lacunar Infarction: Comparison between Dippers and NonDippers. Department of Neurology, Kyoto Second Red Cross Hospital, Kyoto, Japan.

Routledge F, Durdle JM. (2007). Nondipping Blood Pressure Patterns Among Individuals with Essential Hypertension : A Review of The Literature. European Journal of Cardiovascular Nursing 6. Canada. Pages:9-26.

Rachman ME; Muis A, Bintang AK.(2011). Gambaran Pola Tekanan Darah Hipertensi Dippers Dan Nondippers Pada Penderita Strok Akut.

Sierra AD et al.,(2009).Prevalence and Factors Associated with Circardian Blood Pressure Pattern in Hypertensive Patients. Hypertension.

Markum HM.,(2009). Pengaruh Pola Tekanan Darah 24 Jam Terhadap Morbiditas dan 
Analisa perbandingan obat antihipertensi (OHT) dengan kejadian pola tekanan darah nondippers pada penderita hipertensi tanpa strok iskemik

Mortalitas, Kardiovaskuler.www. Jantunghipertensi .com.

Martini FH et al., (2001).Red Blood Cells in Fundamentals of Anatomy \& Physiology $5^{\text {th }}$ ed. Prentice Hall. Upper Saddle River; Pages: 628-637.

Schachter M.,(2010).Diurnal Rhythms, The Renin-Angiotensin System : Circadian Changes in Blood Pressure and Heart Rate. Medscape.

Sherwood L., (2004). Erythrocytes In Human Physiology From Cells to Systems Thomson Books
/Cole. Australia.Pages :293396.
Sullivan et al.,(2012).Relation Of Gender-Specific Risk Of Ischemic Stroke In Patients With Atrial Fibrillation To Differences In Warfarin Anticoagulation Control (from AFFIRM).Am J Cardiol. USA.

Vasan RS., (2001). Assessment of frequency of progression to hypertension in nonhypertensiveparticipants in the Framingham Heart Study: cohort study. Lancet. 